\title{
MODERN TECHNOLOGY'S EFFORT TO MASTER TIME AS A CHALLENGE FOR ETHICS
}

\begin{abstract}
Modern technology has been striving to free humans from their subjection to space and time since its very beginnings. Overcoming spatial distances, intrinsically linked to the phenomenon of globalisation, and the parallel process of gaining mastery over time by new means of production and communication, has promised to bring man closer to a fulfilled life. However, instead of giving us more time for an authentic existence, the acceleration of time in modernity (as analysed by sociologist Hartmut Rosa) has led to a chronic lack of time and poses a general question of a good life and ethics. In this article, I intend to refer to Heidegger's view on the essence of modern technology as an endeavour to win victory over time, and the need of philosophical reflection regarding the positive nature of time. However, authentic time cannot come about without relationships to our fellow humans, and Levinas' account of temporality will serve as both a correction to Heidegger's position and a way towards an ethical consideration of time.
\end{abstract}

Keywords: Technology, time, acceleration, Heidegger, Levinas, Rosa.

\section{Introduction}

We live in a time characterised by a peculiar paradox to time itself: on the one hand we have gained much time through the help of modern technologies, but, on the other, we seem to be suffering from time pressure more than at any other time in history. This dichotomy between our apparent growing mastery and constant lack of time poses various ethical questions that not only relate to moral challenges which require time for well-weighed decisions, as opposed to the increasingly high speeds of new technologies, but more importantly to our contemporary way of life. Since its Greek beginnings, a central question of ethics has revolved around the good life. This question, with its temporal dimension, is still of fundamental importance today, as this is a life in time, and achieving it is intrinsically connected to the question of how one lives or spends their time.

In this paper, I will first present some aspects of the sociological theory on our contemporary time from German sociologist Hartmut Rosa, whose analyses of (post)modern society centre on the concept of social acceleration. He believes that it is by means of temporal structures that we can best understand (post)modern society's development [1], and technological progress plays a key role in this process of acceleration. However, in addition to this sociological analysis we can also ask a philosophical question regarding the existential presuppositions for such a historical development. Heidegger's well-known reflections on the essence of technology aid in discerning the hidden agenda behind this process, which is none other than man's attempt to master time. This striving, however, brings us to fundamental questions about the relationship between our existence and time; between life and temporality, and these questions will be addressed in the last section of the paper.

\section{The paradox of technological acceleration and the scarcity of time}

Rosa's overall ambition is to provide a theory of modernity by analysing the temporal structures which underlie its historical development. The passage from the pre-modern epoch to the modern one is marked by a transition from the "static historical perspective" to a directed process with "the idea of progress" [1, p. 290], which includes a temporal index of its development. Temporality is related to changes to different levels of society, and these changes are taking place at an increasing speed. For Rosa this process of acceleration becomes the distinctive feature of modernity and he distinguishes three dimensions which stand in a close relationship to each other [1, p. 71]. First there is technical acceleration, with the impressive development of science and technology. This acceleration is largely, but not solely, responsible

\footnotetext{
* Branko Klun

Faculty of Theology, University of Ljubljana, Slovenia

E-mail: branko.klun@teof.uni-lj.si
} 
for the acceleration of social change. If we think of periods within which certain technological devices affected and shaped our life until they were succeeded by new devices (e.g. radio, television, internet), and consequently by new ways of social behaviour, a shortening of these time periods can be observed. It is therefore no surprise that this acceleration of social changes also affects individual life experience, and leads to the acceleration of the pace of life. This subjective experience of an increased tempo, which produces a constant feeling of pressure, or lack of time, stands in stark contrast to technical acceleration, which has brought us enormous gains in time, but nevertheless, and paradoxically, leaves us feeling like we have less.

So, the three dimensions enhance each other in what Rosa calls "the circle of acceleration" [1, p. 151]. Technical acceleration provokes an increase of social changes which, in turn, speed up the pace of life. A high-paced life then demands more technical support and faster services, and so the circle is completed acceleration becomes a self-propelling process. Although there are certain obstacles to acceleration, which Rosa describes as categories of inertia (such as natural limits to speed or intentional deceleration) [1, p. 80], these cannot fully stop or reverse the process, and this is further stimulated by other external forces. For example, Rosa speaks of the economic motor (best summed up in the phrase "time is money"), the cultural motor (the imperative of a fulfilled life) and the socio-structural motor (connecting the increasing complexity of today's world) [1, p. 194]. The overall result is the accelerated society which shapes our lives today.

In this presentation I want to focus on a dimension of technical acceleration which Rosa analyses under three aspects [1, p. 104]. Our impressive development of technology first revolutionised our relationship to space (acceleration of transportation), then our relationship to fellow human beings (acceleration of communication), and finally our relationship to things (acceleration of (re)production). First, distances in space are being overcome in increasingly shorter times, and information technology, with its high-speed data transfer, is also contributing to a change in our experience of space. Sociologist Manuel Castells observes a transition from a "space of places" to the "space of flows" [2]. The internet is an extreme example of spacelessness, as events within it seem to happen everywhere and at the same time. Second, information technology has also profoundly changed the realm of communication, which is no longer conditioned by spatial distances and time-consuming mediations (e.g. classical letters), and today there is a visible tendency towards live or realtime reporting. Paul Virilio criticised this "globalized expansion of the present" [3] within his comprehensive diagnosis of modern society. Live-reporting on TV may seem to be closer to "truth", but in reality it includes an increased possibility for manipulation when "individuals are being subconsciously influenced by the omnipresent normative images and messages of economic, political, and cultural marketing ads and media content" [4, p. 135]; the real-time flow of images, which overwhelms the recipient, appeals only to his emotions and leaves no time for reflection. This speed-of-light communication wins over time, but also suppresses our existentially lived temporality, and does not allow recipients to create an integral experience of an event. This same criticism applies to communication between individual persons, as it remains questionable whether an immediate and constant connection increases the quality of their relationship.

Finally, there is the third dimension, our relationship to things, as production times decrease alongside product lifespans. The economic drive of continuous growth in production, which requires an ever-faster rate of consumption, has changed the role and value of things in our lives with far-reaching effects, not only for our environment and its limited resources, but also in terms of our very way of our being. Our existence is caught in a spiral of acceleration: time is constantly being gained by means of technical optimisation, but we experience a perpetual lack or scarcity of it.

\section{Heidegger's account of technology and the question of time}

Jonathan Trejo-Mathys has observed parallels between Rosa's social criticism, based on a temporal-structural approach, and Heidegger's philosophical analysis of the relationship between being and time [5] but he does not further explore their possible convergences. For our purposes, however, it will prove worthwhile to consult Heidegger's philosophical views to better understand the sociological theory of our accelerated society.

Heidegger's interpretation of technology seeks to be more than a mere philosophical analysis of this major phenomenon in modernity: technology is not merely a sum of technological devices and techniques, but is also a special mode of thought, characteristic of our modern age. In order to find the essence of technology we cannot just analyse the technological products which are increasingly inhabiting and determining our world, meaning that the danger of technology lies not only in the devices themselves (e.g. the nuclear bomb). It would be equally shortsighted if we misconceived of technology as a mere instrument at man's disposal, subject to his moral decisions [6]. In the latter case technology would only be as dangerous as man is capable of its misuse and moral failure. Heidegger demands a deeper view of technology and asks transcendental questions: "What makes the whole of technology possible?" and "What sort of human intentional approach to reality stands behind the rise of modern science, which brought about this awesome technological development?" He does not accept the common belief regarding (modern) science as a theoretical fundament for technology and its practical fruits. Rather, he accuses modern, mathematised science as being "technical" at its very essence. Science is "the theory of the real" [6, p. 157], where theoria means a way of viewing and understanding reality. However, this way of viewing and 
approaching the world is not a rational necessity; it is a historical possibility. Heidegger challenges our prevalent opinion of modern science and technology as the peak and highest expression of rationality's historical development. For him, modern (scientific and technological) rationality is a contingent historical event, and belongs to the destiny of Western civilization. Furthermore, this rationality is an event that has brought us away from authentic life, and is largely responsible for what Heidegger refers to as the forgottenness and abandonment of being [7].

I do not intend to enter into a full range discussion on Heidegger's views, and here I am limiting myself to just one aspect which has often been neglected in commentaries on his position regarding technology: the aspect of time. One would look in vain for references to time in Heidegger's major essays on technology, but this issue nevertheless pervades them all. Namely, it is the absence - or more precisely, the forgottenness - of time that constitutes the essence of technology and correlates with the forgottenness of being. Our present age, dominated by technology, is for Heidegger only the last stage in the historical epoch succinctly called metaphysics. Metaphysics does not stand first and foremost for a discipline in philosophy, or for the quest of the suprasensible, but for a specific way of thinking which guided the development of Western thought into a particular direction, and caused a "fall" from authentic being. So, with Plato, as the father of metaphysics, what occurred can be described as a mistrust of time, and an attempt to overcome it. True being was recognised as eidos, or idea - i.e. a timeless essence of things, which is not subject to temporal changes, but "endures as present" [6, p. 20]. Time became a negative connotation, working against stability, and responsible for the contingency and finitude of all being(s).

This metaphysical identification of true being with timelessness (and eternity) has its deepest roots in the existential desire to overcome the temporality and finitude of our own existence. So, gaining mastery over time meant securing a timeless meaning for our finite existence, and behind this attempt to conquer and suppress time Heidegger recognises the will to power and domination. However, according to him, this brings man away from a true and authentic existence, in which time should be acknowledged in a constitutive and positive way. The more we desire to master our existence outside of its lived temporality, the more we lose it. Our being (existence) is given to us in time and above all as (a lived) time. Heidegger thus demands a different attitude towards time and its finitude: it should be honoured as a positive (although finite) horizon, wherein life (or being) is able to come into its own authenticity.

It is now easier to understand Heidegger's provocative thesis that the technological thinking of our modern age is both the heir and completion of Western metaphysics [8]. The essence of technology, according to Heidegger, is "en-framing" [6, p.19] wherein the ancient "idea" reverberates, but in an even more radicalised way. Enframing denotes a certain vision of reality, which is now perceived (Heidegger would say "revealed") as an object at our disposal, and subject to our "framing". The word "frame" conveys the original intention of Heidegger's Gestell, since it stands for a stable structure which has no relation to time. Time itself is "framed" and given a technical meaning: it is conceived of as a linear flow and expressed in a mathematical way. When such technical thinking turns back to the self-understanding of man and his existence, we face the paradox of today: the more we want to technically control and master our life and its lived time, the more we experience this life fading away.

\section{Towards a new consideration of time and the question of meaning}

Social acceleration as described by Rosa can be supported by Heidegger's explanation of the metaphysical desire to master time and escape death. Rosa writes that "acceleration [...] becomes a secular substitute for eternity, a functional equivalent for religious ideas of an eternal life and thus a modern response to death" [1, p. 310]. However, the ambition behind acceleration is accompanied by another experience - despite our ever-faster pace of life, there is a feeling that nothing really new is happening; that there is a rigidity behind this ongoing acceleration and that time is standing still. Virilio describes this phenomenon as a "polar inertia" [9], a constant circular movement in which nothing really changes or moves. Perhaps Heidegger's notion of enframing tries to philosophically address this feeling of standstill in the apparent acceleration. However, while he identifies boredom as the basic mood of our time [10], Rosa points to depression, which has become one of the world's most common sicknesses, and can be "conceived as a pathology of time" [1, p. 248]. Still, both would agree that our unauthentic relationship to time in today's accelerated society cannot be overcome by individual decisions alone. For Rosa, we are embedded in society's temporal structures, which condition our individual life, and Heidegger seems to offer no solution other than a mysterious wait for the advent of a new historical age of (more authentic) being.

Nevertheless, we should not succumb to resignation, and Baudrillard's "ironic vision of the entire scientific and technological process" [11] does not seem to be the right answer either. Baudrillard recognises the consequences of extreme acceleration, which leads to a hyperbolic congestion of time in instantaneity, what the media call real-time, and speaks of a "prefect crime" [12] perpetrated against time itself: "for with the ubiquity and instant availability of the totality of information, time reaches its point of perfection, which is also its vanishing point. Because, of course, a perfect time has no memory and no future" [11, p. 64]. The vanishing of time leads to a vanishing of meaning. This is the crucial point, since real time (instantaneity) allows for no thinking, for no reflection (which by its very prefix "re-" requires a distance that includes a time interval); it remains in the ambiguity of all possible meanings [11, p. 51] and thus falls prey 
to manipulation. For the same reason Virilio holds the view that no politics is possible in real time, and criticises the development of democracy towards "dromocracy" [13] (Gr.: dromos, race). The same can be said for ethics. Despite our increasingly faster technology, man should be able to "take his time" in order to think and ask the question of meaning, and Heidegger sees a direct correlation between meaning and time. Man is the only being who lives in the way of understanding, of giving meaning to his own doing and to the world around him, but this openness to the world and to himself (or man's consciousness) is constituted by his specific (existential) temporality. According to Heidegger, time is not accidental to human subjectivity, but constitutes its very "substance": we not only have time, but we "are" time. This lived time is inextricably linked with our understanding. A meaning - as a constitutive part of understanding - can only be created within a horizon of time. We could say that today's omnipresent acceleration contracts the horizon of time and endangers the constitution of meaning.

The main ethical challenge of today is not the constant effort to safeguard our autonomy by securing safe heavens of (spare) time in the battle against acceleration, but rather the actualisation of the age-old question on the good life, which can also be translated into the question on the meaning of life. Is the good or fulfilled life one which is "filled up" with as many realised options, experiences, and adventures in a lifespan as possible - as the prevailing image of a successful life today seems to suggest? [14]. Or, should we be searching for an alternative, a decelerated way of life, by embracing the nostalgic ideal of a contemplative and simple life, usually accompanied by the romantic refusal of technology altogether?

In conclusion, I would briefly like to refer to an altogether different view of time put forth by Levinas: the bold thesis that time cannot authentically be experienced by an isolated subject [15]. It is only after another person enters my life that I overcome the boring duration of my inauthentic temporality
[16]. For Levinas, the ultimate meaning of time is the paradoxical experience of giving $m y$ time to another person in a living relationship, something which should be conceived of as their ethical responsibility for each other. It is in fact a paradox - as is the entire ethical philosophy of Levinas - because our time seems to be inalienable from us, and cannot be given to another person. Yet, Levinas insists on this possibility as the highest vocation of life, and as a true metaphysical desire beyond the will to power and domination. Even in our age of technology, with our constant lack of time, we still have enough time to give to (or spend for) our fellow humans.

With regard to accelerated time today, it therefore seems to be a twofold task before us. First, we should be able to make time for ourselves, and not allow it to be suppressed by the frenetic circle of acceleration. This, however, does not mean detaching oneself from the commitments of everyday life. Rather, it means having a different attitude towards the actions and events we are engaged in. Heidegger calls this attitude "serenity", or "composure" (Gelassenheit), and takes this notion from Meister Eckhart. In serenity we do not seek to dominate things. Instead, we let them be (seinlassen). In a serene and calm (gelassen) attitude we also let time be; we "give time time". Serenity prevents us from getting absorbed in the frenetic course of our daily routines and allows us to reflect upon the meaning of our doing, and of our life in general. The second task, as advocated by Levinas, refers to the call and needs of other people. Serenity cannot mean a passive tolerance or indifference ("let them be") towards fellow humans, but should lead to an active engagement, in the sense of making time for other people. To have time for others is to give my time a new, transcendent meaning. In such a way, both a serene composure and a responsibility for others represent an alternative way in which to come to terms with today's world of technology and its increasing acceleration. It allows us to be in this world, but not be of it.

\section{References:}

[1] ROSA, H.: Social Acceleration. A New Theory of Modernity. Trans. J. Trejo-Mathys: New York: Columbia University Press, 2013. ISBN 9780231519885 .

[2] CASTELLS, M.: The Information Age: Economy, Society and Culture I.: The Rise of the Network Society, $2^{\text {nd }}$ ed., Oxford: Blackwell, 2010, 453. ISBN 9781405186964.

[3] VIRILIO, P.: Open Sky. Trans. J. Rose. London: Verso, 1997 [1995], 134. ISBN 1859841813.

[4] VALCO, M.: Rethinking the role of Kierkegaard's 'Authentic Individual' in liberal capitalist democracies today. European J. of Science and Theology, vol. 11, No. 5, 2015, 129-139. ISSN 1841-0464. See also: SLIVKA, D.: Vplyv medii na socialne a kulturne hodnoty sucasnosti I. Presov: Presovska univerzita, 2010, 77.

[5] TREJO-MATHYS, J.: Translator's Introduction: Modernity and Time. In H. Rosa: Social Acceleration. A New Theory of Modernity. New York: Columbia University Press, 2013.

[6] HEIDEGGER, M.: The Question Concerning Technology and Other Essays. Trans. W. Lovitt, New York: Garland, 1977, 5. ISBN 0824024273 
[7] HeIDEGGER, M.: Contributions to Philosophy. From Enowning. Trans. P. Emad \& K. Maly. Bloomington: Indiana University Press, 1999, 79ff, ISBN 0253336066.

[8] HEIDEGGER, M.: Mindfulness. Trans. P. Emad \& Th. Kalary. London: Continuum, 2006, 151, ISBN 9781441178404.

[9] VIRILIO, P.: Polar Inertia. Trans. P. Camiller. London: Sage, 2000 [1990]. ISBN 0761958037.

[10] HeIDEgGer, M.: The Fundamental Concepts of Metaphysics. World, Finitude, Solitude. Trans. W. McNeill \& N. Walker. Bloomington: Indiana University Press, 2008, 74. ISBN 9780253214294.

[11] BAUDRILLARD, J.: The Vital Illusion. Ed. J. Witwer. New York: Columbia University Press, 2000, 53. ISBN 0231121008.

[12] BAUDRILlaRD, J.: The Perfect Crime. Trans. C. Turner. London: New York: Verso, 1996 [1995]. ISBN 1859840442.

[13] VIRILIO, P.: Speed and Politics: An Essay on Dromology. Trans. M. Polizzotti. New York: Semiotext(e), 1986 [1977], 46. ISBN 0936756241.

[14] GRONEMEYER, M.: Das Leben als letzte Gelegenheit. Sicherheitsbedürfnisse und Zeitknappheit, $2^{\text {nd }}$ ed., Darmstadt : WBG, 1996. ISBN 9783534801480.

[15] LEVINAS, E.: Time and the Other. Trans. R. A. Cohen. Pittsburgh: Duquesne University Press, 1987, 39. ISBN 0820701831.

[16] Kierkegaard seems to take this point even further, maintaining the human self is essentially relational, as Valco correctly points out. See: VALCO, M.: Kierkegaard's Sickness unto Death as a resource in our search for personal authenticity. European J. of Science and Theology, vol. 12, No. 1, 2016, 97-105. ISSN 1841-0464. "The human self is a true self precisely because it realizes itself and is able to enter into an inner dialogue with itself. This would not be possible, according to Kierkegaard, if human being were a static essence, established without any constitutive relation to the Other.” Ibid. 101. The lack of proper relation of the self to the Other ends, according to Kierkegaard, in despair. 